\title{
Assessment of the Current Grazing Intensity and Slope Status of Pastures in the Alai Valley, Kyrgyzstan
}

\author{
Jie LIU $^{1}$ and Teiji WATANABE ${ }^{2}$
}

\begin{abstract}
This paper assesses grazing intensity and slope status in the Alai Valley, southern Kyrgyzstan using the grazing model of Howard and Higgins (1987) and vegetation-covered area. The grazing intensities of the measured slopes $(\mathrm{N}=173)$ have been classified into three types: (1) slopes without terraces $(\mathrm{N}=84)$, (2) slopes that can accept more livestock $(\mathrm{N}=19)$, and (3) overgrazed slopes $(\mathrm{N}=70)$. Considering the percentage of vegetation cover (threshold $=40 \%$ ), the slopes can be divided into those in good status $(\mathrm{N}=70)$ and those in poor status $(\mathrm{N}=103)$. Three influential factors for grazing intensity and slope status are discussed, i.e., grazing seasonality, distance to the main river, and stocking rate. The results show that $40.5 \%$ of slopes are overgrazed and $59.6 \%$ are evaluated as slopes in poor status. During the fieldwork, 33 households in total were interviewed. The interview results show that the western part of the study area is used as spring and autumn pastures, and that the eastern part is used as summer pastures. Summer grazing has resulted in overgrazing. The distances from the measured slopes to the main river were calculated by GIS. The grazing intensity is greater in the vicinity of the main river, and the slope status improves with the increasing distance to water. The slopes that can accept more livestock are always located at least $500 \mathrm{~m}$ away from the main river. The results show that grazing seasonality, distance to the main river, and stocking rate act as influential factors for the distribution of grazing intensity and slope status.
\end{abstract}

Key words : Alai Valley, grazing intensity, slope status, grazing seasonality, distance to the main river, stocking rate

\section{I . Introduction}

Pastures are regarded as a crucial economic resource in the Kyrgyz Republic (Kyrgyzstan) (Dorre, 2012). Pastures are important for not only the economy but also the country's ecology. Pastureland degradation is believed to have exacerbated in the first decade after the collapse of the Soviet Union (Jansky and Pachova, 2006). The Pamir-Alai Mountains have a great amount of alpine pasture resources. However, there have been no comprehensive studies about the current pastureland degradation in the Pamir-Alai Mountains thus far. In order to prevent the pastures from further ecological damage in the Alai Valley, assessing the current grazing intensity and understanding the slope status are necessary.

Grazing terraces (grazing steps) that made by livestock have been discussed with regard to slope degree, slope distance between steps, and height and weight of livestock to develop a graz-

\footnotetext{
${ }^{1)}$ Graduate School of Environmental Science, Hokkaido University, Japan

${ }^{2)}$ Faculty of Environmental Earth Science, Hokkaido University, Japan
} 
ing model equation for sheep, cattle, and horses (Howard and Higgins, 1987). Watanabe (1994) used this model to assess the grazing intensity by yaks and sheep/goats in the upper valley of the Langtang Himal, central Nepal. However, vegetation cover, an important index of pastureland degradation, has not been considered in the model.

Grazing intensity and slope status have been influenced by several factors. Firstly, the influence of grazing seasonality (pasture use in different seasons) has been discussed in previous research. For instance, a change in grazing seasonality leads to different vegetation productivity levels, species, and structures (Marble and Harper, 1989; Mousel et al., 2003; Metzger et al., 2005). Brougham (1960) showed that frequent hard summer grazing activities resulted in the widespread death of desirable pasture plants in New Zealand. Ludwig (2000) has discussed that the activities of livestock were concentrated in the places near water owing to the animals' physiological dependence. The distribution of water places is described as an important influential factor for the grazing pressure on pastures (Pringle and Landsberg, 2004). A few studies have dis- cussed stocking rate (ha/head), which is defined as the amount of grazing area allocated to each livestock unit (Galt et al., 2000). For instance, the relationship between the degree of stocking rates of reindeer and soil erosion has been discussed in Alaska (Klein, 1987), sub-Antarctic South Georgia (Leader-Williams et al., 1987), and Arctic Canada (Henry and Gunn, 1991).

This study aims to assess grazing intensity and status of grazing slopes based both on the grazing model of Howard and Higgins (1987) and on the data collected from the vegetation-covered area in the Alai Valley. Grazing seasonality, distance to the main river, and stocking rate are discussed as the influential factors on grazing intensity and slope status.

\section{II . Study area}

The Alai Valley $\left(39^{\circ} 30^{\prime} \mathrm{N}-39^{\circ} 42^{\prime} \mathrm{N}, 72^{\circ} 00^{\prime}\right.$ $\mathrm{E}-74^{\circ} 00^{\prime} \mathrm{E}$ ) is located in the southernmost part of the Kyrgyz Republic (Fig. 1). The area of the Alai Valley is $7,910 \mathrm{~km}^{2}$ and the altitude of the valley bottom ranges from 2,240 $\mathrm{m}$ (west) to $3,536 \mathrm{~m}$ (east). The Alai Valley has a continental mountainous climate with cold winters and cool sum-

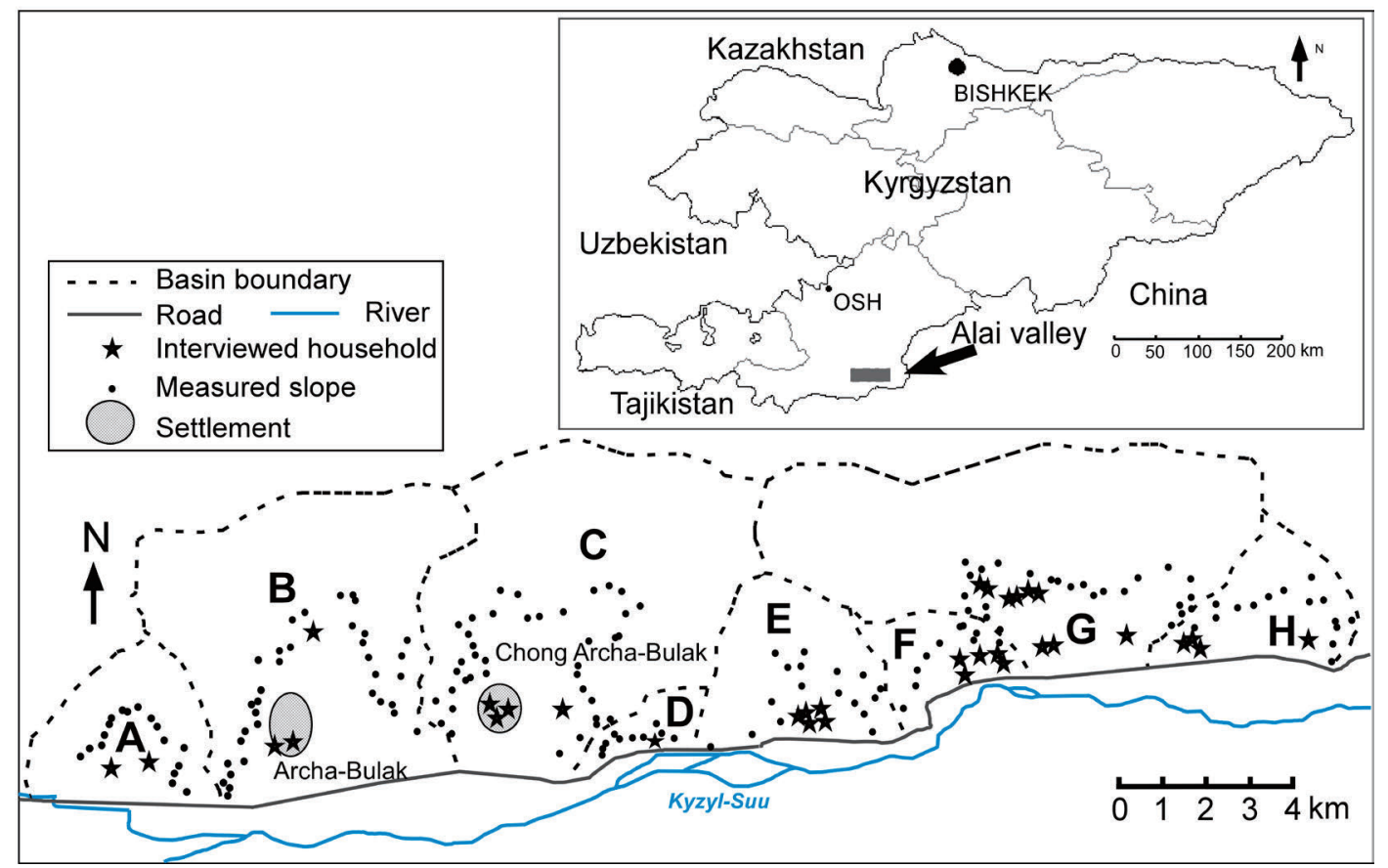

Fig. 1. Study area 
mers (Gaunavinaka, 2010). Summers are dry with water provided by melting snow and glaciers. The coldest month is January with a monthly mean air temperature of $-16.6^{\circ} \mathrm{C}$ and the warmest month is July with a monthly mean air temperature of $9.8^{\circ} \mathrm{C}$ (1935-2000) in Sary-Tash (Williams and Konavalov, 2008). The annual precipitation (1963-2000) is $45.5 \mathrm{~mm}$. The predominant vegetation is alpine steppe (Arase et al., 2013).

This study was conducted in the eastern part of the Alai Valley. The study area was classified into eight basins based on the mountain ridges, and they are defined as basin A to basin $\mathrm{H}$ from west to east (Fig. 1). Settlements named Archa-Bulak and Chong Archa-Bulak are located in basin B and basin C, respectively. The main river, Kyzyl-Suu, runs through the south of basins $\mathrm{A}-\mathrm{H}$, and acts as a water resource to support the daily lives of the local people. Unpublished data obtained from the local administrative office show that, as of 2013, 82 families live in Archa-Bulak and 10 families live in Chong Archa-Bulak. The main types of livestock grazed in basins $\mathrm{A}-\mathrm{H}$ are sheep and goats.

\section{Methods \\ 1. Slope measurement}

In the study area, 173 mid-slopes were selected and measured (Fig. 1). First, the existence of grazing terraces was identified in the field (Fig. 2 ). Then, grazing slopes were classified into those without terraces and those with terraces. The slopes without terraces are regarded to have grazing intensities that are currently not sufficiently heavy to develop grazing terraces on the slopes.

The slopes with terraces were classified into (1) slopes that can accept more livestock and (2) overgrazed slopes by the existing grazing model of Howard and Higgins (1987), as shown in Fig. 2. Slope distance (S) and slope degree were measured for a section (around 10-30 m) of each slope with terraces by a micro total station (TruPulse $360^{\circ} \mathrm{B}$, Laser Technology Inc.), and the number of terraces in the measured section was counted. The mean slope distance between successive steps (SD) was obtained by dividing

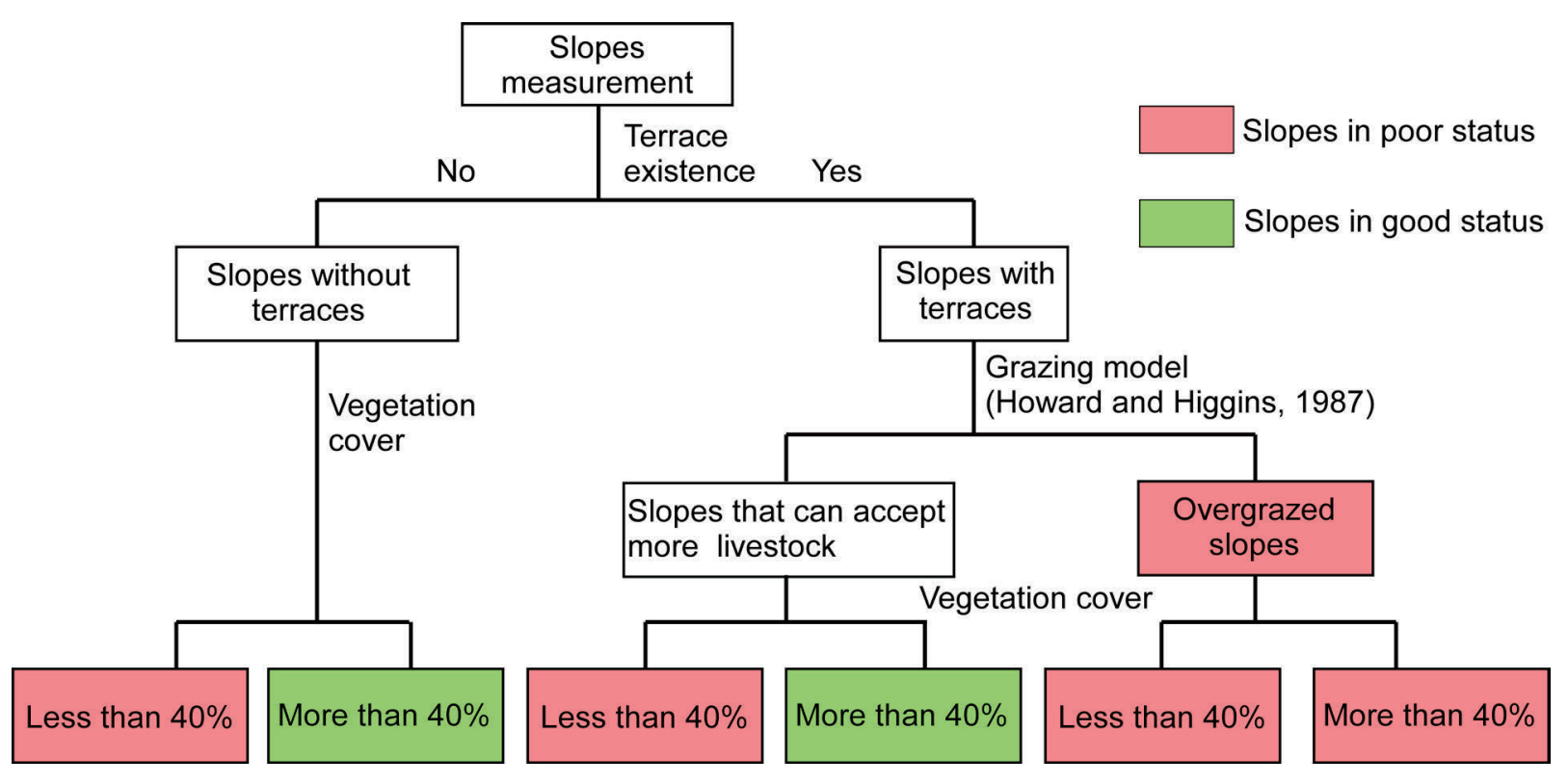

Fig. 2. Process of slope classification 


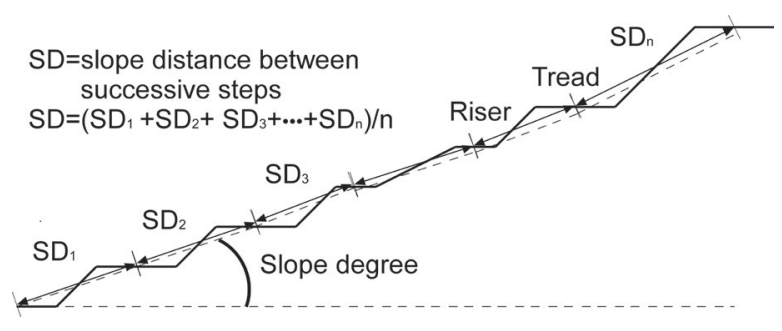

Fig. 3. Schematic diagram showing slope distance between steps (SD) and slope degree along a longitudinal profile of grazing terraces

the slope distance (S) by the number of terraces (Fig. 3). SD and slope degree were used to understand the degree of grazing intensity on the measured slopes. The data of the measured slopes were fitted to the grazing model of Howard and Higgins (1987). The optimal use curve of SD vs. slope degree for sheep was used for the analysis because the main livestock in the study area are sheep and goats. Data plotted on the left side of the optimal curve can be considered as 'overgrazed' (Watanabe, 1994), while the original model has examined only the stocking status on the right side of the optimal curve.

Percentage of vegetation cover is an important criterion of slope status. Thornes (1988) stated that $40 \%$ vegetation cover is a critical threshold, below which erosion could be accelerated on a slope. This study adopts $40 \%$ vegetation cover as a threshold of slope status.

Finally, the measured slopes were classified into six types after applying the threshold of the percentage of vegetation cover into the classification of the grazing intensity (Fig. 2): (1) slopes without terraces (vegetation cover $\leq 40 \%)$; (2) slopes without terraces (vegetation cover $>$ 40\%); (3) slopes that can accept more livestock (vegetation cover $\leq 40 \%$ ); (4) slopes that can accept more livestock (vegetation cover $>40 \%$ ); (5) overgrazed slopes (vegetation cover $\leq 40 \%$ ); and (6) overgrazed slopes (vegetation cover $>40 \%$ ).

For this study, the slopes without terraces (vegetation cover $>40 \%$ ) and the slopes that can accept more livestock (vegetation cover $>40 \%$ ) are regarded as slopes in good status (green in Fig. 2). The remaining four types of slopes were considered as slopes in poor status (red in Fig. 2).

\section{Interviews}

Altogether, 33 households were interviewed both in the summer of 2011 and in the summer of 2012 (Fig. 1). Households (total $\mathrm{N}=26$ ) in all the basins, except basins $\mathrm{B}$ and $\mathrm{C}$, were interviewed. Because the villages of Archa-Bulak and Chong Archa-Bulak exist in basins B and C, sample interviewed households were randomly selected $(\mathrm{N}=7)$. The information collected during the interviews includes the grazing period in the study area and the number of livestock. Based on grazing seasonality (different seasonal period of grazing), the interviewed households were classified into two types: (1) spring \& autumn users, and (2) summer users.

\section{GIS}

The geographic information describing the measured slopes and houses or yurts (movable tents) of the interviewed households was recorded by an altimeter and a handheld GPS. After mapping the locations of the measured slopes and houses or yurts at a scale of 1: 50,000 using ArcGIS, the distances from the measured slopes to the main river (Kyzyl-Suu) were measured. The area of each basin was also measured using ArcGIS.

\section{Results and discussion}

\section{Grazing intensity and slope status}

Among the 173 measured slopes, 84 slopes have no grazing terraces and the other 89 slopes have terraces (Table 1). According to the optimal use curve (Howard and Higgins, 1987) (Fig. 4), 70 slopes with terraces were identified as overgrazed (data that were plotted on the left side of the optimal use curve) and 19 slopes were identified as slopes that can accept more livestock (data that were plotted on the right side of the optimal 
Table 1. Classification of the measured slopes

\begin{tabular}{|c|c|c|c|c|c|c|c|c|c|c|c|c|}
\hline \multirow[b]{4}{*}{$\begin{array}{l}\text { Percentage } \\
\text { of the } \\
\text { vegetation } \\
\text { cover }\end{array}$} & \multicolumn{9}{|c|}{ Grazing intensity } & \multirow{3}{*}{\multicolumn{3}{|c|}{ Slope status }} \\
\hline & \multirow{2}{*}{\multicolumn{3}{|c|}{ Slopes without terraces }} & \multicolumn{6}{|c|}{ Slopes with terraces } & & & \\
\hline & & & & \multicolumn{3}{|c|}{ Slopes that can accept more livestock } & \multicolumn{3}{|c|}{ Overgrazed slopes } & & & \\
\hline & $\leqslant 40 \%$ & $>40 \%$ & Total & $\leqslant 40 \%$ & $>40 \%$ & Total & $\leqslant 40 \%$ & $>40 \%$ & Total & $\begin{array}{l}\text { Slopes } \\
\text { in good } \\
\text { status }\end{array}$ & $\begin{array}{c}\text { Slopes } \\
\text { in poor } \\
\text { status }\end{array}$ & Total \\
\hline \multirow{2}{*}{$\begin{array}{l}\text { Slopes' } \\
\text { number }\end{array}$} & 26 & 58 & 84 & 7 & 12 & 19 & 36 & 34 & 70 & 70 & 103 & 173 \\
\hline & $15.0 \%$ & $33.5 \%$ & $48.5 \%$ & $4.0 \%$ & $6.9 \%$ & $11.0 \%$ & $20.8 \%$ & $19.7 \%$ & $40.5 \%$ & $40.4 \%$ & $59.6 \%$ & $100.0 \%$ \\
\hline
\end{tabular}

Table 2. Grazing intensity, slope status, and stocking rate in basins $\mathrm{A}-\mathrm{H}$

\begin{tabular}{|c|c|c|c|c|c|c|c|c|c|c|c|c|c|c|c|c|c|}
\hline \multirow[b]{2}{*}{$\begin{array}{l}\text { Type of } \\
\text { pastures }\end{array}$} & \multirow[b]{2}{*}{ Basin } & & \multicolumn{3}{|c|}{ Slopes without terraces } & \multicolumn{3}{|c|}{$\begin{array}{l}\text { Slopes that can accept more } \\
\text { livestock }\end{array}$} & \multicolumn{3}{|c|}{ Overgrazed slopes } & \multicolumn{3}{|c|}{ Slope status } & \multirow[b]{2}{*}{$\begin{array}{c}\text { Area } \\
\text { (ha) }\end{array}$} & \multirow{2}{*}{$\begin{array}{l}\text { Live- } \\
\text { stock } \\
\text { number }\end{array}$} & \multirow{2}{*}{$\begin{array}{l}\text { Stocking } \\
\text { rate } \\
\text { (ha/head) }\end{array}$} \\
\hline & & $\begin{array}{c}\text { Vegeta- } \\
\text { tion } \\
\text { cover }\end{array}$ & $\leq 40 \%$ & $>40 \%$ & Total & $\leq 40 \%$ & $>40 \%$ & Total & $\leq 40 \%$ & $>40 \%$ & Total & $\begin{array}{l}\text { Slopes } \\
\text { in good } \\
\text { status }\end{array}$ & $\begin{array}{l}\text { Slopes } \\
\text { in poor } \\
\text { status }\end{array}$ & Total & & & \\
\hline \multirow{5}{*}{$\begin{array}{c}\text { Spring \& } \\
\text { autumn } \\
\text { pastures }\end{array}$} & \multicolumn{2}{|l|}{ A } & $\begin{array}{r}0 \\
0.0 \%\end{array}$ & $\begin{array}{r}13 \\
72.2 \%\end{array}$ & $\begin{array}{r}13 \\
72.2 \%\end{array}$ & $\begin{array}{r}1 \\
5.6 \%\end{array}$ & $\begin{array}{r}0 \\
0.0 \%\end{array}$ & $\begin{array}{r}1 \\
5.6 \%\end{array}$ & $\begin{array}{r}1 \\
5.6 \%\end{array}$ & $\begin{array}{r}3 \\
16.7 \%\end{array}$ & $\begin{array}{r}4 \\
22.3 \%\end{array}$ & $\begin{array}{r}13 \\
72.2 \%\end{array}$ & $\begin{array}{r}5 \\
27.8 \%\end{array}$ & $\begin{array}{r}18 \\
100.0 \%\end{array}$ & 408.4 & 130 & 3.1 \\
\hline & \multirow{2}{*}{\multicolumn{2}{|c|}{ B }} & & 14 & 23 & 3 & 2 & 5 & 5 & 5 & 10 & 16 & 22 & & 1239.5 & 1,606 & 0.8 \\
\hline & & & $\begin{array}{r}.7 \% \\
9\end{array}$ & $\begin{array}{r}36.8 \% \\
12\end{array}$ & $\begin{array}{r}60.5 \% \\
21\end{array}$ & $\begin{array}{r}7.9 \% \\
2\end{array}$ & $\begin{array}{r}5.3 \% \\
2\end{array}$ & $\begin{array}{r}13.2 \% \\
4\end{array}$ & $\begin{array}{r}13.2 \% \\
8\end{array}$ & $\begin{array}{r}13.2 \% \\
6\end{array}$ & $\begin{array}{r}26.4 \% \\
14\end{array}$ & $\begin{array}{r}42.1 \% \\
14\end{array}$ & $\begin{array}{r}57.9 \% \\
25\end{array}$ & $\begin{array}{r}100.0 \% \\
39\end{array}$ & & & \\
\hline & \multicolumn{2}{|l|}{ C } & $23.1 \%$ & $30.8 \%$ & $53.9 \%$ & $5.1 \%$ & $5.1 \%$ & $10.2 \%$ & $20.5 \%$ & $15.4 \%$ & $35.9 \%$ & $35.9 \%$ & $64.1 \%$ & $100.0 \%$ & 1365.6 & 4,000 & 0.3 \\
\hline & \multicolumn{2}{|l|}{ Total } & $\begin{array}{r}18 \\
18.9 \% \\
\end{array}$ & $\begin{array}{r}39 \\
41.1 \% \\
\end{array}$ & $\begin{array}{r}57 \\
60.0 \%\end{array}$ & $\begin{array}{r}6 \\
6.3 \%\end{array}$ & $\begin{array}{r}4 \\
4.2 \% \\
\end{array}$ & $\begin{array}{r}10 \\
10.5 \%\end{array}$ & $\begin{array}{r}14 \\
14.7 \%\end{array}$ & $\begin{array}{r}14 \\
14.7 \%\end{array}$ & $\begin{array}{r}28 \\
29.5 \%\end{array}$ & $\begin{array}{r}43 \\
45.3 \% \\
\end{array}$ & $\begin{array}{r}52 \\
54.7 \%\end{array}$ & $\begin{array}{r}95 \\
100.0 \%\end{array}$ & 3013.5 & 5,736 & 0.5 \\
\hline \multirow{6}{*}{$\begin{array}{l}\text { Summer } \\
\text { pastures }\end{array}$} & \multicolumn{2}{|l|}{$\mathrm{D}$} & $\begin{array}{r}0 \\
0.0 \%\end{array}$ & $\begin{array}{r}1 \\
10.0 \%\end{array}$ & $\begin{array}{r}1 \\
10.0 \%\end{array}$ & $\begin{array}{r}0 \\
0.0 \%\end{array}$ & $\begin{array}{r}0 \\
0.0 \%\end{array}$ & $\begin{array}{r}0 \\
0.0 \%\end{array}$ & $\begin{array}{r}5 \\
50.0 \%\end{array}$ & $\begin{array}{r}4 \\
40.0 \%\end{array}$ & $\begin{array}{r}9 \\
90.0 \%\end{array}$ & $\begin{array}{r}1 \\
10.0 \%\end{array}$ & $\begin{array}{r}9 \\
90.0 \%\end{array}$ & $\begin{array}{r}10 \\
100.0 \%\end{array}$ & 117.2 & 100 & 1.2 \\
\hline & \multicolumn{2}{|l|}{$\mathrm{E}$} & $\begin{array}{r}0 \\
0.0 \%\end{array}$ & $\begin{array}{r}6 \\
35.3 \%\end{array}$ & $\begin{array}{r}6 \\
35.3 \%\end{array}$ & $\begin{array}{r}0 \\
0.0 \%\end{array}$ & $\begin{array}{r}4 \\
23.5 \%\end{array}$ & $\begin{array}{r}4 \\
23.5 \%\end{array}$ & $\begin{array}{r}3 \\
17.6 \%\end{array}$ & $\begin{array}{r}4 \\
23.5 \%\end{array}$ & $\begin{array}{r}7 \\
41.2 \%\end{array}$ & $\begin{array}{r}10 \\
58.8 \%\end{array}$ & $\begin{array}{r}7 \\
41.1 \%\end{array}$ & $\begin{array}{r}17 \\
100.0 \%\end{array}$ & 468.0 & 150 & 3.1 \\
\hline & \multicolumn{2}{|l|}{$\mathrm{F}$} & $\begin{array}{r}3 \\
30.0 \%\end{array}$ & $\begin{array}{r}2 \\
20.0 \%\end{array}$ & $\begin{array}{r}5 \\
50.0 \%\end{array}$ & $\begin{array}{r}0 \\
0.0 \%\end{array}$ & $\begin{array}{r}0 \\
0.0 \%\end{array}$ & $\begin{array}{r}0 \\
0.0 \%\end{array}$ & $\begin{array}{r}4 \\
40.0 \%\end{array}$ & $\begin{array}{r}1 \\
10.0 \%\end{array}$ & $\begin{array}{r}5 \\
50.0 \%\end{array}$ & $\begin{array}{r}2 \\
20.0 \%\end{array}$ & $\begin{array}{r}8 \\
80.0 \%\end{array}$ & $\begin{array}{r}10 \\
100.0 \%\end{array}$ & 201.1 & 220 & 0.9 \\
\hline & \multicolumn{2}{|l|}{ G } & $\begin{array}{r}1 \\
3.8 \%\end{array}$ & $\begin{array}{r}8 \\
30.8 \%\end{array}$ & $\begin{array}{r}9 \\
34.6 \%\end{array}$ & $\begin{array}{r}1 \\
3.8 \%\end{array}$ & $\begin{array}{r}4 \\
15.4 \%\end{array}$ & $\begin{array}{r}5 \\
19.2 \%\end{array}$ & $\begin{array}{r}3 \\
11.5 \%\end{array}$ & $\begin{array}{r}9 \\
34.6 \%\end{array}$ & $\begin{array}{r}12 \\
46.1 \%\end{array}$ & $\begin{array}{r}12 \\
46.2 \%\end{array}$ & $\begin{array}{r}14 \\
53.7 \%\end{array}$ & $\begin{array}{r}26 \\
100.0 \%\end{array}$ & 1325.7 & 650 & 2.0 \\
\hline & \multicolumn{2}{|l|}{$\mathrm{H}$} & $\begin{array}{r}4 \\
26.7 \%\end{array}$ & $\begin{array}{r}2 \\
13.3 \%\end{array}$ & $\begin{array}{r}6 \\
40.0 \%\end{array}$ & $\begin{array}{r}0 \\
0.0 \%\end{array}$ & $\begin{array}{r}0 \\
0.0 \%\end{array}$ & $\begin{array}{r}0 \\
0.0 \%\end{array}$ & $\begin{array}{r}7 \\
46.7 \%\end{array}$ & $\begin{array}{r}2 \\
13.3 \%\end{array}$ & $\begin{array}{r}9 \\
60.0 \%\end{array}$ & $\begin{array}{r}2 \\
13.3 \%\end{array}$ & $\begin{array}{r}13 \\
86.7 \%\end{array}$ & $\begin{array}{r}15 \\
100.0 \%\end{array}$ & 320.0 & 630 & 0.5 \\
\hline & \multicolumn{2}{|l|}{ Total } & $\begin{array}{r}8 \\
10.3 \%\end{array}$ & $\begin{array}{r}19 \\
24.4 \%\end{array}$ & $\begin{array}{r}27 \\
34.6 \%\end{array}$ & $\begin{array}{r}1 \\
1.3 \%\end{array}$ & $\begin{array}{r}8 \\
10.3 \%\end{array}$ & $\begin{array}{r}9 \\
11.5 \%\end{array}$ & $\begin{array}{r}22 \\
28.2 \%\end{array}$ & $\begin{array}{r}20 \\
25.6 \%\end{array}$ & $\begin{array}{r}42 \\
53.8 \%\end{array}$ & $\begin{array}{r}27 \\
34.6 \%\end{array}$ & $\begin{array}{r}51 \\
65.4 \%\end{array}$ & $\begin{array}{r}78 \\
100.0 \%\end{array}$ & 2432.0 & 1,750 & 1.4 \\
\hline
\end{tabular}

use curve). Table 1 indicates that only $40.5 \%$ of the slopes are overgrazed and the remaining slopes $(48.5 \%)$ have not developed terraces. These data suggest that the grazing intensity is not very severe in the study area. Figure 5 shows the distribution of different types of grazing intensity on the measured slopes. It is noteworthy that basin $\mathrm{D}$ has the largest percentage of overgrazed slopes (90.0\%): the grazing intensity in basin $\mathrm{D}$ is quite severe (Table 2).

Figure 6 shows the distribution of slope status in each basin. Considering the percentage of vegetation cover (Table 1), $40.4 \%$ of the measured slopes have been designated as slopes in good status (slopes without terraces with vegetation cover $>40 \%$ and slopes that can accept more livestock with vegetation cover $>40 \%$ ). A majority $(59.6 \%)$ of the measured slopes in the study area are classified as being in poor status. Most

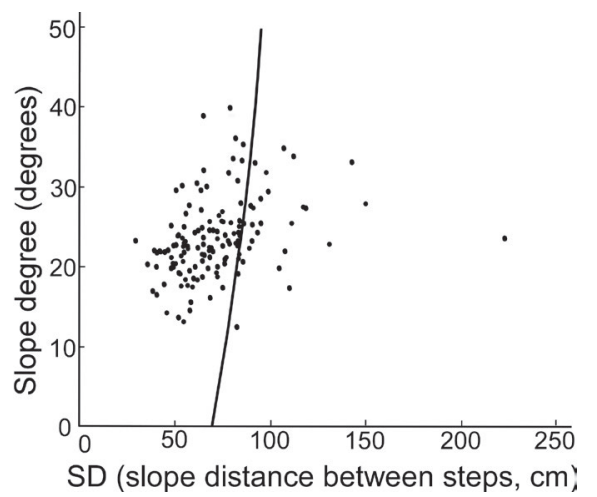

Fig. 4. Slope distance between steps (SD) vs. slope degree for the sheepgrazing slopes in the Alai Valley $(\mathrm{N}=89)$

The curve, called the optimal curve (Howard and Higgins, 1987), indicates the grazing intensity of slopes. 


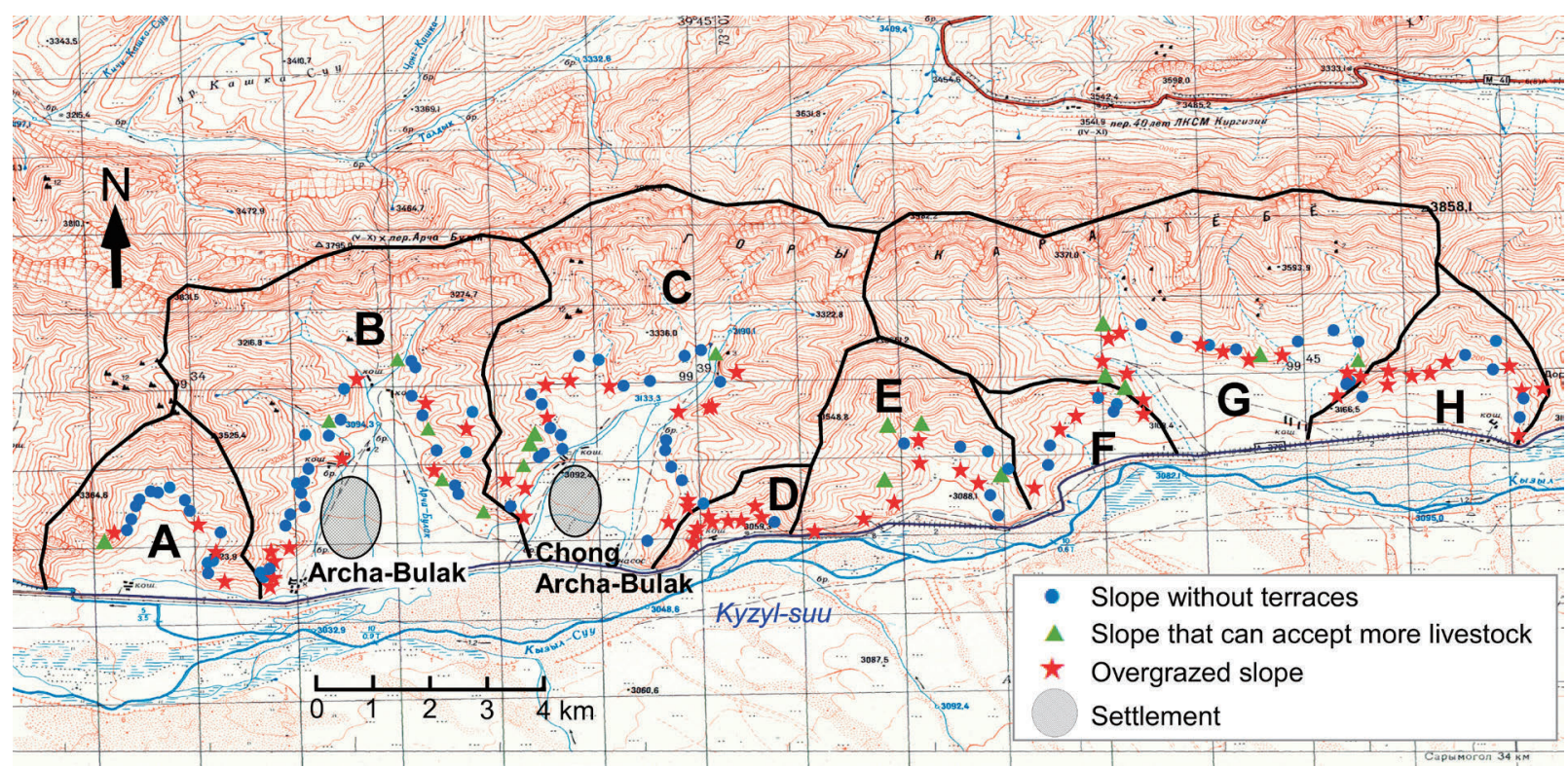

Fig. 5. Distribution of the three types of grazing intensity

A-H show the classified basins. Base map: Soviet 1:50,000 topographic map J-43-3-B.

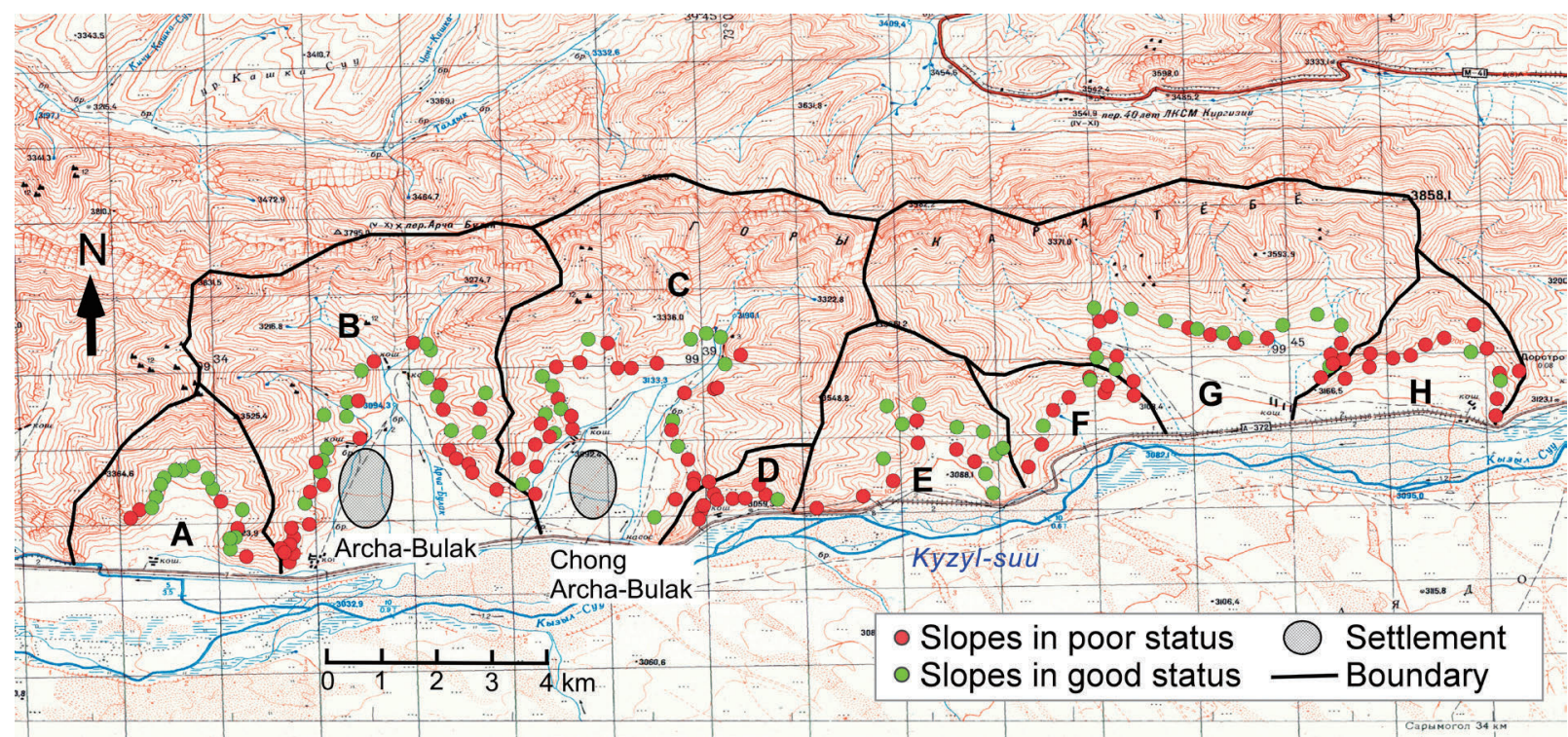

Fig. 6. Distribution of slope status

A-H show the classified basins. Base map: Soviet 1:50,000 topographic map J-43-3-B.

measured slopes in basin $\mathrm{D}$ are in poor status.

\section{Influential factors}

\section{(1) Grazing seasonality}

The interview results show that there are three types of occupation periods for the households in the study area: (1) eight households are occupied all year round in the study area; (2) two households are occupied from autumn to spring (from September to the end of next May); and (3) the remaining 23 households are occupied in summer (from June to September) only.

The first two types of households have permanent houses in the basins. Moreover, they graze their livestock on the slopes around their houses twice a year: during the early spring (from mid- 


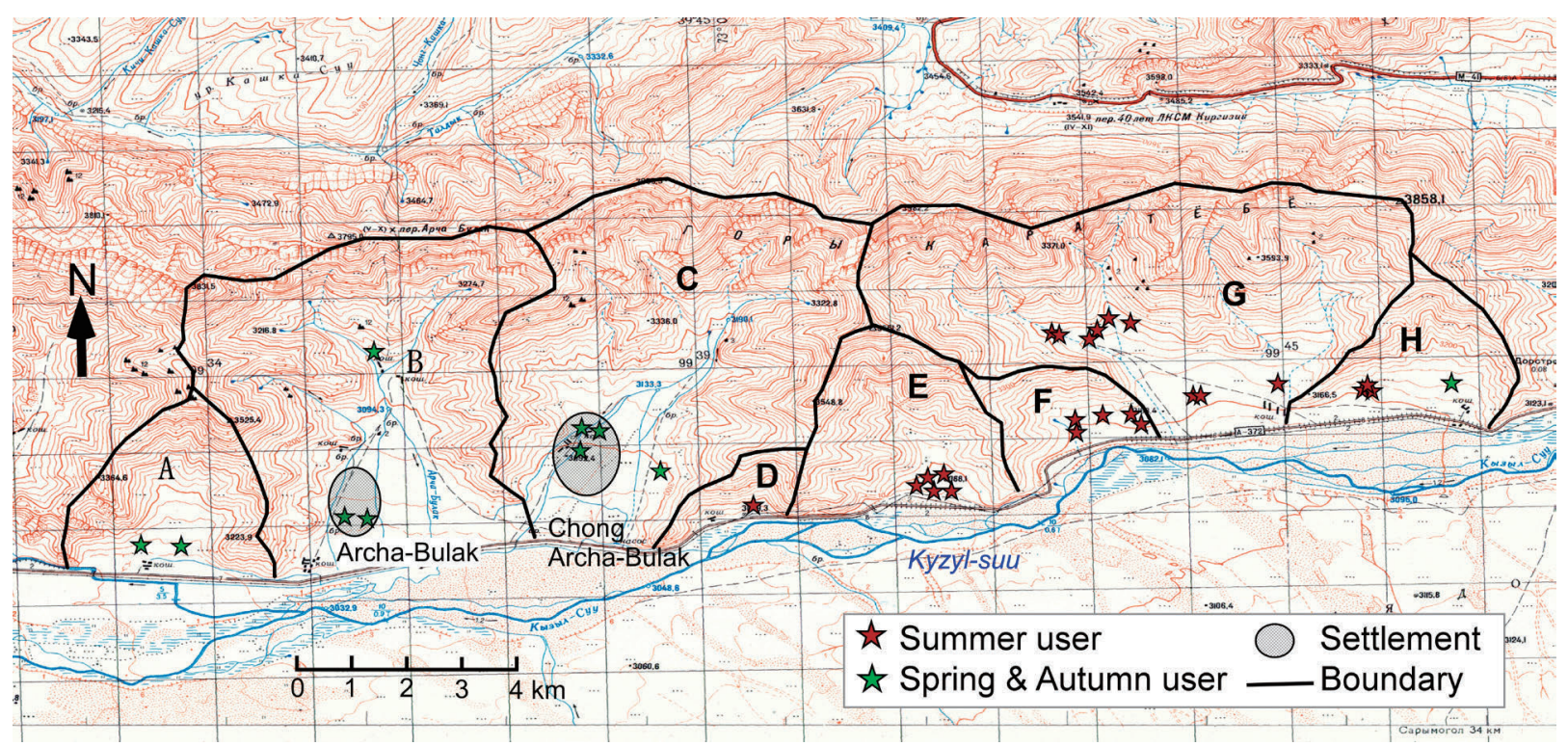

Fig. 7. Distribution of occupation periods of the interviewed families

A-H show the classified basins. Base map: Soviet 1:50,000 topographic map J-43-3-B.

April to the end of May) and late autumn (from mid-September to mid-November). In winter, they keep their livestock in shelters attached to their houses and feed them with fodder. They graze their livestock in summer pastures, which are far away from their permanent houses. These two types of households are primarily residents in the western part of the study area (basins AC), and they are classified as spring and autumn users (Fig. 7). The pastures that they use (basins A-C) are defined as spring and autumn pastures. The third type, i.e., the households who stay and graze livestock in the basins in summer, are regarded as summer users, and the pastures that they use can be defined as summer pastures (basins D-H) (Fig. 7). They have permanent houses in their hometowns, which are far away from their summer pastures. In spring and autumn, they graze their livestock in pastures located near their hometowns.

In summary, it can be concluded that the western half of the study area is used as a permanent occupation place and the eastern half of the study area is used as a seasonal (summer only) occupation place. The interview results explain that such a difference in the seasonal patterns of pastureland use is due to water availability. The water resource in the eastern half of the study area is sufficient for daily life only in summer, and no families could survive there in other seasons.

Table 2 shows that the average percentage of slopes without terraces in basins A-C (60.0\%) is larger than that in basins $\mathrm{D}-\mathrm{H}$ (34.6\%). Table 2 also shows that the average percentage of overgrazed slopes in basins D-H (53.8\%) is substantially higher than that in basins A-C (29.5\%). Summer grazing, which is conducted in basins $\mathrm{D}-\mathrm{H}$, could be one of the factors that cause the more severe overgrazing problem. This situation is supported by previous studies conducted elsewhere: McMeekan et al. (1945) discussed that the growth of plants in pastures in summer was insufficient for the daily requirements of livestock, and Brougham (1960) observed that the widespread death of desirable pasture plants occurred when grazing was severe in summer.

\section{(२) Distance to the main river (Kyzyl-Suu)}

The main river (Kyzyl-Suu) acts as the staple water resource not only for the daily life of the local households but also for the livestock. The 


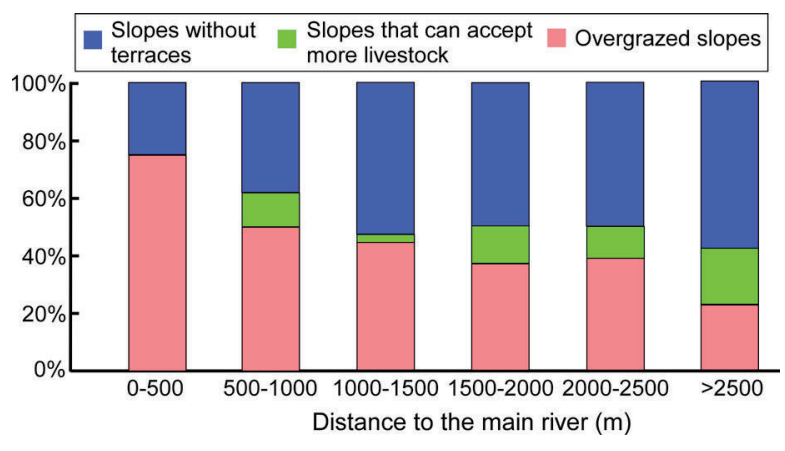

Fig. 8. Percentages of grazing intensity in different distance

ranges from the measured slopes to the main river

average distance from the 173 slopes to the river (Kyzyl-Suu) was 1,655 m. The average distances from the overgrazed slopes, slopes that can accept more livestock, and slopes without terraces were $1,410 \mathrm{~m}, 1,903 \mathrm{~m}$, and $1,803 \mathrm{~m}$, respectively. In order to analyze the relationship between grazing intensity/slope status and the distance to the main river, the distances to the main river were classified into six categories: $0-500 \mathrm{~m}$, 500-1,000 m, 1,000-1,500 m, 1,500-2,000 m, $2,000-2,500 \mathrm{~m}$, and $>2,500 \mathrm{~m}$.

Figure 8 shows that, with increasing distance to the main river, the percentage of slopes without terraces increases and the percentage of overgrazed slopes decreases. It also shows that the slopes that can accept more livestock are always located at least $500 \mathrm{~m}$ away from the main river. Basin D, which is located closest to the main river (average distance $=509 \mathrm{~m}$ ), has the largest percentage of overgrazed slopes (90\%; Table 2). This result is consistent with previous research (Valentine, 1947; Ludwig, 2000), which stated that the activity of livestock is concentrated in the vicinity of water and reduces rapidly with increasing distance to water. Moreover, Pringle and Landsberg (2004) discussed how distance to water could be incorporated in spatial models to predict cumulative grazing pressure. In conclusion, the high proportion of overgrazed slopes in the area near the main river is closely related to the high grazing pressure.

Figure 9 shows that with decreasing distance

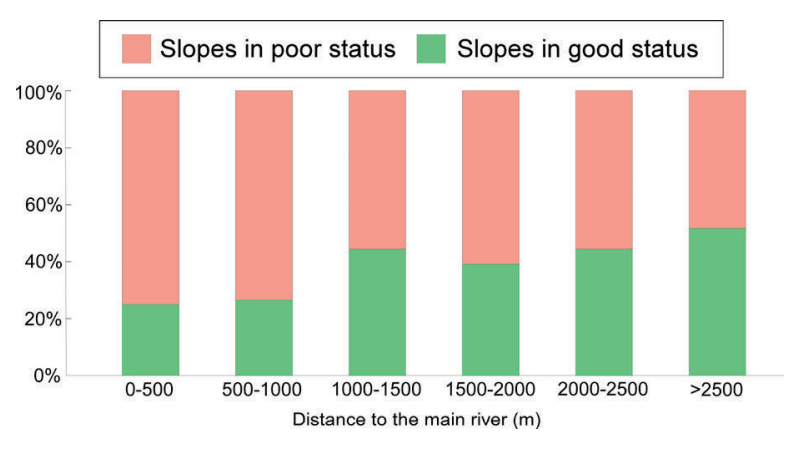

Fig. 9. Percentages of slope status in different distance ranges from the measured slopes to the main river

to the main river, the percentage of slopes in good status decreases. Because basin D is located closest to the main river (average distance $=509$ $\mathrm{m})$, that basin has the largest percentage of slopes in poor status (90\%; Table 2). The results shown in Fig. 9 can be explained by the description above, i.e., higher grazing pressure in the vicinity of the main river leads to more occurrences of poor slope status.

In summary, the results above demonstrate that the distance to a drinkable water resource acts as an influential factor for the distributions of grazing intensity and slope status. In order to recover the slope status in the vicinity of the main river, the grazing pressure should be decreased. It is suggested that potable water resources should be exploited in the underused pastures, which are far from the main river. Besides, there are vast pastures to the south of the main river, many of which have not been used since the independence in 1991. This is primarily because of the lack of bridges. Building bridges is suggested to decrease the current grazing pressure occurring in the study area.

\section{(3) Stocking rate (ha/head)}

Table 2 shows that basin A has the highest stocking rate ( $3.1 \mathrm{ha} / \mathrm{head})$ among the spring and autumn pastures (basins $\mathrm{A}-\mathrm{C}$ ), and that it has the largest percentage of slopes without terraces. Basins B and C have lower stocking rates ( 0.8 ha/head and $0.3 \mathrm{ha} /$ head, respectively), which 
indicate that high grazing pressure exists in these two basins. The stocking rate is an influential factor for the existence of grazing terraces in the spring and autumn pastures.

In summer pastures (basins D-H) basins D, $\mathrm{F}$, and $\mathrm{H}$ have low stocking rates $(1.2 \mathrm{ha} / \mathrm{head}$, $0.9 \mathrm{ha} /$ head, and $0.5 \mathrm{ha} /$ head, respectively), while basins $\mathrm{E}$ and $\mathrm{G}$ have high rates (3.1 ha/head and 2.0 ha/head, respectively). Basins $\mathrm{D}, \mathrm{F}$, and $\mathrm{H}$ have larger percentages of overgrazed slopes and smaller percentages of slopes that can accept more livestock, in comparison with basins $\mathrm{E}$ and G. This suggests that the stocking rate is an influential factor on grazing intensity in the summer pastures as well.

Table 2 also shows that basins $\mathrm{B}$ and $\mathrm{C}$ have more slopes in poor status (60.9\% and $64.1 \%$ ), and the same situation occurs in some of the summer pastures (basins D-H): basins D, F, and $\mathrm{H}$ have more slopes in poor status $(90.0 \%, 80.0 \%$, and $86.7 \%$, respectively). In conclusion, the stocking rate (ha/head) plays an important role in the slope status as well.

Because the slopes in poor status indicate that they have a higher possibility to have land erosion, we can say that the stocking rate is also an influential factor on the occurrence of erosion. This also agrees with previous studies: the places where reindeer are grazed at rates of 1.5-2.5 ha/ head (Leader-Williams et al., 1987) has more erosion, compared with the places where they are grazed at 4-8 ha/head (Henry and Gunn, 1991) and $5.6 \mathrm{ha} /$ head (Klein, 1987).

\section{Conclusions}

This study assessed grazing intensity and slope status in the eastern part of the Alai Valley, southern Kyrgyzstan, using the grazing model of Howard and Higgins (1987) and the percentage of vegetation-covered area. Only $40.5 \%$ of measured slopes were classified as overgrazed, and the majority of the measured slopes (59.6\%) were defined as slopes in poor status.
The results concerning grazing seasonality show that summer grazing has led to more overgrazing. Grazing intensity was greater in the vicinity of the main river, and the slope status showed a tendency to be better on the slopes farther away from the main river. The slopes that can accept more livestock were at least 500 $\mathrm{m}$ away from the main river. Moreover, a lower stocking rate (ha/head), which indicates higher grazing density, was likely to result in more slopes with terraces in spring and autumn pastures, and in more overgrazed slopes in summer pastures. Lower stocking rates caused more slopes to be in poor status in both spring and autumn pastures as well as summer pastures.

Basin D had the highest percentage of overgrazed slopes (90.0\%) and poor slope status (90.0\%), although the stocking rate (1.2 ha/head) was not the lowest in the study area. The combination of grazing seasonality (summer grazing) and the shortest distance to the main river was the causes of the overgrazing and the poor status in basin D.

\section{Acknowledgement}

This study was funded by the Grant-in-Aid for Scientific Research, Japan Society for the Promotion of Science (Grant Nos. 20251001 and 23251001). JL received research fund from the Japan Science Society.

\section{References}

Arase, T., Liu, J. and Watanabe, T. (2013): Degeneration of alpine steppe vegetation around Sary-Tash Village, Kyrgyz Republic. Geographical Studies, 88, 60-69.

Brougham, R.W. (1960): The effects of frequent hard grazing at different times of the year on the productivity and species yields of a grass-clover pasture. New Zealand Journal of Agricultural Research, 3, 125-136.

Dorre, A. (2012): Legal arrangements and pasture-related socio-ecological challenges in Kyrgyzstan. In: Kreutzmann, H., editor. Pastoral Practices in High Asia, Advances in Asian High Environmental Research, Netherlands, Springer, pp127-144. 
Galt, D., Molinar, F., Navarro, J., Joseph, J. and Holechek, J. (2000): Grazing capacity and stocking rate. Rangelands, 22(6), 7-11.

Gaunavinaka, L. (2010): Regional difference by an analysis of main land use/land cover and bioregional conditions in the Kyrgyz part of the Pamir-Alai Transboundary Conservation Area (PATCA). Master's Thesis submitted to Hokkaido University.

Henry, G. and Gunn, A. (1991): Recovery of tundra vegetation after overgrazing by caribou in arctic Canada. Arctic, 44, 38-42.

Howard, J.K. and Higgins, C.G. (1987): Dimensions of grazing-step terracettes and their significance. In: Gardiner, V., editor. International Geomorphology, Part II, 545-568.

Jansky, L. and Pachova, N.I. (2006): Towards sustainable land management in mountain areas in Central Asia. Global Environmental Research, 10, 99-115.

Klein, D.R. (1987): Vegetation recovery patterns following overgrazing by reindeer on St. Matthew Island. Journal of Range Management, 40, 336-338.

Leader-Williams, N., Smith, R.I. L. and Rothery, P. (1987): Influence of introduced reindeer on the vegetation of South Georgia: results from a long-term exclusion experiment. Journal of Applied Ecology, 24, 801-822.

Ludwig, J.A., Bastin, G.N., Eager, R.W., Karfs, R., Ketner, P. and Pearce, G. (2000): Monitoring Australian rangeland sites using landscape function indicators and ground and remote-based techniques. Monitoring Ecological Condition in the Western United States, 64, 164-78.

Marble, J.R. and Harper, K.T. (1989): Effect of timing of grazing on soil-surface cryptogamic communities in a great basin low-shrub desert: a preliminary report. Western North American Naturalist, 49(1), 104-107.

McMeekan, C.P., Campbell, I.L., Cooper, M.M., Stevens, P.G. and Ward, A.H. (1945): Principles of Animal Production. Christchurch, N.Z., London, and Melbourne, Whitcombe \& Tombs Ltd.

Metzger, K.L., Coughenour, M.B., Reich, R.M. and Boone, R.B. (2005): Effects of seasonal grazing on plant species diversity and vegetation structure in a semi-arid ecosystem. Arid Environments, 61, 147-160.

Mousel, E.M., Schacht, W.H. and Moser, L.E. (2003): Summer grazing strategies following early season grazing of big bluestem. Agronomy, 95, 1240-1245.

Pringle, H.J. and Landsberg, J.R. (2004): Predicting the distribution of livestock grazing pressure in rangelands. Austral Ecology, 29, 31-39.

Thornes, J.B. (1988): Erosional equilibria under grazing. In: Bintliff, J., Davidson, D. and Grant, E., editors. Conceptual Issues in Environmental Archaeology, Edinburgh University Press, pp193-210.

Watanabe, T. (1994): Soil erosion on yak-grazing steps in the Langtang Himal, Nepal. Mountain Research and Development, 14, 171-179.

Williams, M.W. and Konovalov, V.G. (2008): Central Asia temperature and precipitation Data, 1879-2003. Boulder, USA National Snow and Ice Data Center. Digital media.

Valentine, K.A. (1947): Distance from water as a factor in grazing capacity of rangeland. Journal of Forestry, 45, 749-754.

(Accepted on 25 September 2013) 